\begin{tabular}{|c|c|c|}
\hline JURNAL PENELITIAN KESMASY & VOL. 1 NO. 2 & $\begin{array}{c}\text { EDITION: NOVEMBER } 2018- \\
\text { APRIL } 2019\end{array}$ \\
\hline & http://ejournal.delihusada.ac.id/index.php/JPKSY & \\
\hline RECEIVED: 17 FEBRUARI 2019 & REVISED: 18 MARET 2019 & ACCEPTED: 28 APRIL 2019 \\
\hline
\end{tabular}

\title{
HUBUNGAN SANITASI LINGKUNGAN DENGAN KEJADIAN INFEKSI SALURAN PERNAFASAN AKUT (ISPA) PADA BALITA DI DESA MARENDAL I PASAR V KAB. DELI SERDANG TAHUN 2018
}

\author{
Nurmala Sari, Diana Rahmadani Siregar \\ Institut Kesehatan Deli Husada, Jl.Besar No. 77 Deli Serdang \\ e-mail : nurmala71@gmail.com
}

\begin{abstract}
Infection of exhalation Acude (ISPA), is one of the main painfulness because for children under five years old in developing countries. The aims of this research was to know the relationship between environmental sanitation forincluded houseventilation, air pollution, andaccupancydensity. The conducted of this research in November 2018 in Marendal I Pasar $\checkmark$ Deli Serdang. Regency theobservational research with cross sectional approach. The subject were all of the house which have children under five years old with 54 respondents sample. The technique of sample used cluster random sampling. The statistical test used chi square test by using Statistical product and service solutions version 20 program. The resultof this research indicated that there was a relationship between house ventilation, air pollution and accupancy density with the occurrence of ISPA (Infection of exhalation Acude). Poor ventilation can cause high humidity and endanger health so that the incidence of Infection of exhalation Acude will increase. The condition of a dense residence can increase the air pollution factor in the house. And the floor area of a healthy home building must be enough for the residents inside. The area of a building that is not proportional to the number of occupants can cause easy disease. lack of oxygen, dirty air can invite various chemicals so it is easy to trigger the disease that comes, Every citizen is expected to always pay attention and try so that his house meets health requirements such as house ventilation, residential density in the bedroom, and healthy air pollution.
\end{abstract}

Keywords : Infection, Exhalation Acute, environmental sanitation.

\section{PENDAHULUAN}

Menurut WHO tahun 2013 di dunia angka terjadinya kematian anak akibat pneumonia atau infeksi saluran pernafasan akut yang dapat mempengaruhi kerusakan paru paru dinyatakan 1,2 juta anak meninggal setiap tahunnya. Sehingga ada 230 orang anak yang meninggal stiap jam di dunia akibat dari pneumonia. (WHO, 2013 ).

Infeksi Saluran Pernafasan Akut merupakan penyakit yang dapat menyebabkan terjadinya kematian pada anak, Penyakit ISPA ini dapat menyebabkan terjadinya penyakit Pneumonia,
Bronchitis dan lainnya yang merupakan penyebab kematian anak yang ke empat dan kasus ini terbanyak terjadi pada anak dibawah tahun. Pada tahun 2013 data dari Riskesdas bahwa penyakit Infeksi Saluran Pernafasan Atas dapat diakibatkan oleh virus / bakteri yang yang ditandai dengan penderita panas dan disertai salah satu atau lebih gejala (Batuk Berdahak, Nyeri saat menelan, Batuk Kering, dan Nyeri tenggorokan. (Kemenkes RI , 2013) .

Pada tahun 2015 menurut WHO, Infeksi Saluran Pernafasan Atas merupakan penyebab dari $15 \%$ kematian balita. Penyakit Pneumonia dapat terjadi pada berbagai wilayah, namun 


\begin{tabular}{c|c|c}
\hline JURNAL PENELITIAN KESMASY & VOL. 1 NO. 2 & $\begin{array}{c}\text { EDITION: NOVEMBER 2018 - } \\
\text { APRIL 2019 }\end{array}$ \\
\hline \multirow{2}{*}{ RECEIVED: 17 FEBRUARI 2019} & http://ejournal.delihusada.ac.id/index.php/JPKSY & ACCEPTED: 28 APRIL 2019 \\
\cline { 2 - 3 } & REVISED: 18 MARET 2019 & ACE
\end{tabular}

penyakit ini paling banyak terjadi di Asia Selatan dan Afrika sub-Sahara. Sejak tahun 1984, WHO telah menerapkan suatu program pemberantasan penyakit ISPA khususnya pada kasus pneumonia dan pada tahun 1990 dilaksanakan Konferensi Tingkat Tinggi (KTT) di New York, dari hasil tersebut telah dibuat kesepakatan untuk menurunkan angka kematian anak akibat ISPA ebesar 30\%, dalam memberantas penyakit ISPA sudah banyak strategi yang telah dilakukan oleh banyak negara termasuk Indonesia, namun hasil yang dicapai di setiap Negara bervariasi. (Rahajoe, 2010).

Pembangunan kesehatan dalam menurunkan angka kematian pada anak selalu berupaya agar dilaksanakan oleh semua komponen Bangsa Indonesia sehingga tujuan dalam meningkatkan kemampuan hidup, kemauan dan kesadaran masyarakat serta kemampuan hidup sehat bagi setiap orang dapat terwujud, sehingga dapat meningkatkan derajat kesehatan masyarakat yang maksimal. Bangsa Indonesia membuat Program Indonesia Sehat pada tahun 2015 - 2019 dengan sasaran meningkatkan derajat kesehatan dan status gizi masyarakat melalui upaya kesehatan dan pemberdayaan masyarakat. Salah satu sasaran pokok pembangunan kesehatan yaitu meningkatnya pengendalian penyakit termasuk penyakit ISPA Infeksi Saluran Pernapasan Akut. (Kemenkes RI, 2015).

Menurut Depkes RI (2014), di Indonesia pada tahun 2014 angka kematian akibat ISPA pada balita sebesar 8 per 10.000 balita, lebih rendah dibandingkan dengan tahun 2013 yang sebesar 119 per 10.000 balita. Pada kelompok bayi usia 0-12 bulan angka kematian lebih tinggi yaitu sebesar 11 per 10.000 bayi jika dibandingkan pada kelompok umur 1-4 tahun yaitu hanya sebesar 6 per 10.000 balita, Infeksi saluran pernafasan akut adalah penyakit infeksi akut yang dapat menyerang salah satu bagian / lebih dari saluran pernafasan yaitu mulai dari hidung, alveoli termasuk adneksanya (sinus rongga telinga tengah pleura). (Depkes, 2013).

Infeksi saluran pernafasan akut (ISPA) merupakan penyakit ketujuh dari 10 pola penyakit terbanyak dengan jumlah kasus 4,463. Selama tahun 2012, ditemukan 41,291 balita menderita infeksi saluran pernafasan akut (ISPA) dengan cakupan penemuan $32,4 \%$, sedangkan dalam tahun 2013 cakupan penemuan dan penanganan penderita penyakit mencapai $100 \%$ (Profil Sumatera Utara)

\section{METODE}

Jenis Penelitian ini adalah penelitian Observasional yang bertujuan untuk mengetahui hubungan antara sanitasi lingkungan dengan kejadian Infeksi Saluran Pernafasan Akut pada balita di Desa Marendal I Pasar V Kab. Deli Serdang Tahun 2018 dengan system pendekatan cross sectional, yaitu dengan cara observasi atau pengumpulan data pada saat yang sama (Notoadmodjo, 2010 ). Pada penelitian ini jumlah pertanyaan dalam kuesioner sejumlah 20 soal yang terdiri dari ventilasi rumah, kepadatan hunian, pencemaran udara, untuk mempermudah menghitung skor dari jawaban yang masuk melalui kuesioner yang digunakan rumus yaitu :

$i=\frac{\text { range }}{\text { jumlah alternatif jaw aban }}$

Keterangan :

I adalah interval

Range adalah skor maksimum + skor minimum

\section{HASIL DAN PEMBAHASAN} Karakteristik Responden

Distribusi Kejadian ISPA berdasarkan Pendidikan, Pekerjaan, Umur Balita, Jenis Kelamin Balita dapat dilihat pada tabel dibawah: 


\begin{tabular}{|c|c|c|}
\hline JURNAL PENELITIAN KESMASY & VOL. 1 NO. 2 & $\begin{array}{c}\text { EDITION: NOVEMBER } 2018- \\
\text { APRIL } 2019\end{array}$ \\
\hline & http://ejournal.delihusada.ac.id/index.php/JPKSY & \\
\hline RECEIVED: 17 FEBRUARI 2019 & REVISED: 18 MARET 2019 & ACCEPTED: 28 APRIL 2019 \\
\hline
\end{tabular}

Tabel 1. Karakteristik Responden

\begin{tabular}{lcc}
\hline Pendidikan & Jumlah & $\begin{array}{c}\text { Persentase } \\
(\%)\end{array}$ \\
\hline Tamat SD & 15 & 27,8 \\
Tamat SMP & 25 & 46,3 \\
Tamat SMA & 8 & 14,8 \\
Tamat PT & 6 & 11,1 \\
\hline Pekerjaan & & \\
\hline Petani & 21 & 38,9 \\
Buruh & 14 & 25,9 \\
Wiraswasta & 10 & 18,5 \\
PNS & 9 & 16,7 \\
\hline Umur Balita & & \\
\hline 2 tahun & 16 & 29,6 \\
3 tahun & 14 & 25,9 \\
4 tahun & 10 & 18,6 \\
5 tahun & 14 & 25,9 \\
\hline Jenis Kelamin Balita & & \\
\hline Laki-laki & 29 & 53,7 \\
Perempuan & 25 & 46,3 \\
\hline Total & 54 & 100,0 \\
\hline
\end{tabular}

Berdasarkan tabel 1 Distribusi Frekuensi Pendidikan Terakhir SMP yaitu sebanyak 25 orang dengan persentase $(46,3 \%)$, dan minoritas responden berpendidikan Perguruan Tinggi (PT) yaitu sebanyak 6 orang dengan persentase $(11,1 \%)$. Distribusi frekuensi Pekerjaan terbanyak yaitu Petani sebanyak 21 orang dengan persentase $(38,9 \%)$, dan minoritas responden PNS yaitu sebanyak 9 orang dengan persentase $(16,7 \%)$. Distribusi frekuensi Umur Balita terbanyak yaitu umur 2 tahun sebanyak 16 orang dengan persentase $(29,6 \%)$, dan minoritas responden pada balita umur 4 tahun yaitu sebanyak 10 orang dengan persentase $(18,6 \%)$.Distribusi frekuensi Jenis Kelamin Balita laki-laki sebanyak 29 orang dengan persentase $(53,7 \%)$, dan minoritas Jenis Kelamin balita Perempuan yaitu sebanyak 25 orang dengan persentase (46,3\%).

\section{Analisis Univariat}

Analisis Univariat dalam penelitian ini berdasarkan variabel kejadian ISPA Ventilasi rumah, Kepadatan Hunian, Pencemaran udara dapat dilihat pada tabel berikut :

Tabel 2. Distribusi Frekuensi Ventilasi Rumah, Kepadatan Hunian dan Pencemaran Udara

\begin{tabular}{lcc}
\hline $\begin{array}{l}\text { Ventilasi } \\
\text { Rumah }\end{array}$ & Jumlah & $\begin{array}{c}\text { Persentase } \\
(\%)\end{array}$ \\
\hline Tidak Ada & 24 & 44,4 \\
Ventilasi & 30 & 55,6 \\
Ada & \\
Ventilasi & & \\
\hline $\begin{array}{l}\text { Kepadatan } \\
\text { Hunian }\end{array}$ & & \\
\hline Tidak baik & 31 & 57,4 \\
Baik & 23 & 42,6 \\
\hline $\begin{array}{l}\text { Pencemaran } \\
\text { Udara }\end{array}$ & \\
\hline Tidak Terjadi & 31 & 57,4 \\
Terjadi & 23 & 42,6 \\
\hline ISPA & 22 & \\
\hline Tidak ISPA & 32 & 50,7 \\
ISPA & 54 & 100,0 \\
\hline \multicolumn{1}{c}{ Total } &
\end{tabular}

Berdasarkan table 2 Menunjukkan bahwa mayoritas responden dengan yang memiliki ventilasi rumah yaitu sebanyak 30 orang dengan persentase $(55,6 \%)$, dan minoritas responden yang tidak memiliki ventilasi rumah yaitu sebanyak 24 orang dengan persentase (44,4\%). Distribusi frekuensi kepadatan hunian menunjukkan bahwa mayoritas responden dengan padat hunian sebanyak 31 orang $(57,4$ $\%)$, dan yang padat hunian sebanyak 23 orang $(42,6 \%)$. Distribusi frekuensi pencemaran udara Menunjukkan bahwa mayoritas tidak terjadi pencemaran udara yaitu sebanyak 31 orang dengan persentase $(57,4 \%)$, dan terjadi pencemaran udara yaitu sebanyak 23 orang dengan persentase $(42,6 \%)$. Distribusi 


\begin{tabular}{|c|c|c|}
\hline JURNAL PENELITIAN KESMASY & VOL. 1 NO. 2 & $\begin{array}{c}\text { EDITION: NOVEMBER } 2018- \\
\text { APRIL } 2019\end{array}$ \\
\hline & http://ejournal.delihusada.ac.id/index.php/JPKSY & \\
\hline RECEIVED: 17 FEBRUARI 2019 & REVISED: 18 MARET 2019 & ACCEPTED: 28 APRIL 2019 \\
\hline
\end{tabular}

frekuensi Menunjukkan bahwa mayoritas responden yang menderita ISPA yaitu sebanyak 32 orang ( 59,3\%), dan minoritas responden yang Tidak terjadi ISPA yaitu sebanyak 22 orang (40, 7\%).

\section{Analisis Bivariat}

Analisis Bivariat berdasarkan variabel Ventilasi Rumah dengan kejadian ISPA dapat dilihat di tabel 3. berikut:

Tabel 3. Ventilasi Rumah dan ISPA

\begin{tabular}{|c|c|c|c|c|c|c|}
\hline \multirow[t]{3}{*}{$\begin{array}{c}\text { Ventilasi } \\
\text { rumah }\end{array}$} & \multicolumn{6}{|c|}{$\begin{array}{l}\text { Infeksi Saluran Pernapasan Akut } \\
\text { (ISPA) }\end{array}$} \\
\hline & & $\overline{Y a}$ & & Tidak & & Total \\
\hline & $\mathbf{F}$ & $(\%)$ & $\mathbf{F}$ & (\%) & $\mathbf{F}$ & $(\%)$ \\
\hline Baik & 8 & 33,3 & 16 & 66,7 & 24 & 100 \\
\hline $\begin{array}{l}\text { Tidak } \\
\text { baik }\end{array}$ & 24 & 80,8 & 6 & 20,0 & 30 & 100 \\
\hline Total & 32 & 59,3 & 22 & 40,7 & 54 & 100 \\
\hline
\end{tabular}

Tabel 3 di atas menunjukkan bahwa dari 24 responden yang memiliki ventilasi baik yang menderita ISPA sebanyak 8 orang $(33,3 \%)$ dan yang tidak menderita ISPA sejumlah 16 orang $(66,7 \%)$. Dari 30 responden yang memiliki ventilasi rumah tidak baik yang menderita ISPA sejumlah 24 orang $(80,8 \%)$ dan yang tidak menderita ISPA sejumlah 6 orang ( 20\%). Hasil uji statistic dengan menggunakan uji chisquare ( $P$-value) diperoleh $P$ Value sebesar $0,001<0,05$ yang menunjukkan bahwa ada hubungan yang signifikan antara ventilasi rumah dengan kejadian ISPA di Desa Marendal I Pasar V Kab. Deli Serdang tahun 2018

Tabel 4. Padatan Hunian dan ISPA

\begin{tabular}{ccccccc}
\hline $\begin{array}{c}\text { Padatan } \\
\text { Hunian }\end{array}$ & \multicolumn{6}{c}{ Infeksi Saluran Pernapasan Akut } \\
& \multicolumn{4}{c}{ Ya } & \multicolumn{2}{c}{ Tidak } \\
& F & $\mathbf{( \% )}$ & $\mathbf{F}$ & $\mathbf{( \% )}$ & $\mathbf{F}$ & Total \\
& & $\mathbf{( \% )}$ \\
Padat & 14 & 45.2 & 17 & 54.8 & 31 & 100 \\
Tidak & 18 & 78.3 & 5 & 21.7 & 23 & 100 \\
Total & 32 & 59,3 & 22 & 40,7 & 54 & 100 \\
\hline
\end{tabular}

Berdasarkan table 4 menunjukkan bahwa dari 31 yang padat hunian terjadi ISPA sebanyak 14 orang $(45,2 \%$ dan tidak ISPA sebanyak 17 orang $(54,8 \%)$ sedangkan dari 23 yang tidak padat hunian yang terjadi ISPA sejumlah 18 orang $(78,3 \%)$ dan tidak ISPA sejumlah 5 orang $(21,7 \%)$, Hasil analisis statistik dengan uji Chi square didapatkan nilai $p(0,03)$ lebih kecil dari nilai a $(0,05)$, dengan demikian terdapat hubungan antara Kepadatan Hunian dengan Terjadinya ISPA di di Desa Marendal I Pasar V Kab. Deli Serdang tahun 2018

Tabel 5. Pencemaran Udara dan ISPA

\begin{tabular}{|c|c|c|c|c|c|c|}
\hline \multirow{4}{*}{$\begin{array}{l}\text { Pence- } \\
\text { maran } \\
\text { Udara }\end{array}$} & \multicolumn{6}{|c|}{$\begin{array}{c}\text { Infeksi Saluran Pernapsan Akut } \\
\text { (ISPA) }\end{array}$} \\
\hline & \multirow{2}{*}{\multicolumn{2}{|c|}{ ISPA }} & \multirow{2}{*}{\multicolumn{2}{|c|}{$\begin{array}{l}\text { Tidak } \\
\text { ISPA }\end{array}$}} & \multirow{2}{*}{\multicolumn{2}{|c|}{ Total }} \\
\hline & & & & & & \\
\hline & $\mathbf{F}$ & $(\%)$ & $\mathbf{F}$ & (\%) & $\mathbf{F}$ & $(\%)$ \\
\hline Terjadi & 13 & 41,9 & 18 & 58,1 & 31 & 100 \\
\hline Tidak & 19 & 82,6 & 4 & 17,4 & 23 & 100 \\
\hline Total & 32 & 59,3 & 22 & 40,7 & 54 & 100 \\
\hline
\end{tabular}

Berdasarkan table 5 diatas menunjukkan bahwa dari 31 yang terjadi pencemaran udara menderita ISPA sejumlah 13 orang $(41,9 \%)$ dan yang tidak ISPA sejumlah 18 orang $(58,1$ $\%)$ dan dari 23 yang tidak terjadi pencemaran udara menderita ISPA sejumlah 19 orang $(82,6$ $\%)$ dan yang tidak menderita ISPA sejumlah 4 orang $(17,4 \%)$ berdasarkan hasil uji statistic dengan menggunakan chi-square ( $p$-value) sebesar $0,006<0,05$ yang menunjukkan bahwa ada hubungan yang signifikan antara pencemaran udara dengan kejadian ISPA di Desa Marendal I Pasar V Kab. Deli Serdang tahun 2018.

\section{Hubungan antara Ventilasi Rumah dengan Kejadian ISPA}

Hasil analisis statistik dengan uji Chi square untuk hubungan antara ventilasi rumah dengan kejadian ISPA pada balita di Desa Marendal, didapatkan nilai $p(0,001)$ lebih kecil dari nilai $a$ $(0,05)$, dengan demikian terdapat hubungan 


\begin{tabular}{c|c|c}
\hline JURNAL PENELITIAN KESMASY & VOL. 1 NO. 2 & $\begin{array}{c}\text { EDITION: NOVEMBER 2018 - } \\
\text { APRIL 2019 }\end{array}$ \\
\hline \multirow{2}{*}{ RECEIVED: 17 FEBRUARI 2019} & http://ejournal.delihusada.ac.id/index.php/JPKSY & ACCEPTED: 28 APRIL 2019 \\
\cline { 2 - 3 } & REVISED: 18 MARET 2019 & A
\end{tabular}

Hasil ini sejalan dengan hasil penelitian (Sulistyorini 2015), di Desa Marendal I, yang menyimpulkan bahwa ventilasi rumah di Desa Marendal rata-rata tidak di buka pada siang hari, dan jarang membersihkan jendela sehingga sering terjadi kelembaban dalam ruangan yang tidak sehat. Responden yang memiliki ventilasi baik dan terkena ISPA sebanyak 24 rumah (80\%) sedangkan responden yang tidak terkena ISPA mempunyai ventilasi rumah yang baik sebanyak 6 rumah (20\%) dan ventilasi rumah yang tidak baik dan terkena ISPA sebanyak $8(33,3)$ dan yang tidak memiliki ventilasi tidak baik yang tidak terkena ISPA sebanyak 16 rumah (66,7\%).

\section{Hubungan antara Kepadatan Hunian dengan Kejadian ISPA}

Hasil analisis statistik dengan uji Chi square untuk hubungan antara kepadatan hunian dengan kejadian ISPA pada balita di Desa Marendal, didapatkan nilai $p(0,030)$ lebih kecil dari nilai $a(0,05)$, dengan demikian terdapat hubungan yang signifikan antara kepadatan hunian dengan kejadian ISPA. Hasil di Desa Marendal I, yang menyimpulkan bahwa kepadatan hunian di Desa Marendal rata-rata memiliki kamar yang sempit. Responden yang memiliki kepadatan hunian yang baik yang terkena ISPA sebanyak 18 rumah (78,3\%) dan yang memiliki kepadatan hunian baik yang tidak terkena ISPA sebanyak 5 rumah $(21,7 \%)$, sedangkan responden yang tidak mempunyai kepadatan hunian yang tidak baik sebanyak 14 rumah $(45,2 \%)$ dan yang tidak mempunyai kepadatan hunian yang tidak baik yang tidak terkena ISPA sebanyak 17 rumah (54,8\%).

Menurut (Sarwono 2010) tentang persyaratan kesehatan perumahan yang tidak sehat dan memenuhi syarat, dimana kepadatan hunian yang melebihi standar dapat menyebabkan suhu ruangan meningkat akbibat aktifitas penghuni rumah, pada kondisi luas rumah yang cukup akan memberikan ruang gerak yang cukup dan memberikan perasaan yang nyaman bagi penghuninya. hal ini disebabkan karena padatnya jumlah keluarga yang berada dalam satu kamar yang dapat menyebabkan kurangnya konsumsi oksigen, dan mudah menularkan penyakit pada keluarga yang lainnya

\section{Hubungan antara Pencemaran Udara dengan Kejadian ISPA}

Hasil analisis statistik dengan uji Chi square untuk hubungan antara Pencemaran udara dengan kejadian ISPA pada balita di Desa Marendal, didapatkan nilai $p(0,006)$ lebih kecil dari nilai $a(0,05)$, dengan demikian terdapat hubungan yang signifikan antara pencemaran udara dengan kejadian ISPA. Hasil di Desa Marendal I, yang menyimpulkan bahwa pencemaran udara di Desa Marendal rata rata. Responden yang mencemari udara terkena ISPA sebanyak 19 rumah (82,6\%) dan yang mencemari udara yang tidak terkena ISPA sebanyak 4 rumah $(17,4 \%)$, sedangkan responden yang tidak mencemari udara terkena ISPA sebanyak 13 rumah $(41,9 \%)$ dan yang tidak mencemari yang tidak terkena ISPA sebanyak 18 rumah $(58,1 \%)$. Hal ini disebabkan karena banyak nya folusi udara yang tidak sehat didalam rumah maupun diluar rumah, sehinggan mudah merasakan sesak yang diakibatkan kurangnya oksigen, udara yang kotor dapat mengundang berbagai bahan kimia sehingga mudah memicu penyakit.

\section{KESIMPULAN}

Berdasarkan hasil penelitian yang telah dilakukan terhadap 54 responden yang ada di Desa Marendal I Pasar V Kab.Deli Serdang, dapat disimpulkan ada hubungan yang signifikan antara Ventilasi Rumah dengan kejadian ISPA pada Balita dengan uji chi- Square ( $P$ value $=0,001<0,05)$, Ada hubungan yang signifikan antara Kepadatan Hunian dengan kejadian ISPA Pasa Balita ( $p$ value 0,030<0,05), dan Ada hubungan yang signifikan antara Pencemaran 


\begin{tabular}{c|c|c}
\hline JURNAL PENELITIAN KESMASY & VOL. 1 NO. 2 & $\begin{array}{c}\text { EDITION: NOVEMBER 2018 - } \\
\text { APRIL 2019 }\end{array}$ \\
\hline \multirow{2}{*}{ RECEIVED: 17 FEBRUARI 2019} & http://ejournal.delihusada.ac.id/index.php/JPKSY & ACCEPTED: 28 APRIL 2019 \\
\cline { 2 - 3 } & REVISED: 18 MARET 2019 & A
\end{tabular}

Udara dengan kejadian ISPA Pasa Balita ( $p$ value $0,006<0,05$ )

\section{DAFTAR PUSTAKA}

Ambarwati dan Dina, 2007. Hubungan antara Sanitasi Fisik Rumah Susun (Kepadatan Penghuni, Ventilasi, Suhu, Kelembaban, dan Penerangan Alami) dengan Kejadian Penyakit ISPA. Abstrak Penelitian. di akses 09 Desember 2008

Alex, 2012. Sukses mengolah sampah organik menjadi pupuk organik. Pustaka Baru Press. Yogyakatra.

Atika, 2012, Perilaku Hidup Sehat dan Bersih. Jakarta : Salemba Medika.

Azwar, A., 1990. Pengantar IImu Kesehatan Lingkungan. Jakarta: Mutiara

Benih, C., 2013. Penanggulangan dan Pengobatan ISPA. Diakses: 09 Desember 2008

Candra, 2010. Pengantar Kesehatan Lingkungan Jakarta: EGC.

Dainur, 2011. IImu Kesehatan Masyarakat. Jakarta: Widya

Depkes RI, 2013. Informasi tentang ISPA pada Balita. Jakarta: Pusat Penyuluhan kesehatan masyarakat

Dinata, A., 2007. Aspek Teknis dalam Penyehatan Rumah. Diakses: 09 Desember 2008

Dinkes Kota Medan, 2016. Profil Kesehatan Kota Medan Tahun 2016. Kemenkes, RI, 2015.

Profil kesehatan Indonesia. Jakarta: Kementerian Kesehatan Indonesia RI. 2016.

Kemenkes, RI, 2010, Pedoman tatalaksana Balita Direktoral Jenderal Pengendalian Penyakit dan Penyehatan Lingkungan. Jakarta

Kisna, 2016. Tempat Pengolahan Sampah. Jakarta : EGC

Khin, M, T, 2005. Indoor Air Polution : Inpact of intervention onAcute. Respirotory
Infection in Under five Chihdern. Regional Healt forum volume 9, (1).

Kotari, Murti, B., 1997. Prinsip dan Metode Riset Epidemiologi. Yogyakarta: Gajah Mada Universitas 2006.

Kusnoputranto, 2011. Kesehatan Lingkungan. Jakarta : Enjang Indan

Margono, 2010. Metode Penelitian Pendidikan, Jakarta : Rineka Cipta

Maryunani, 2010. Persyaratan Rumah Sehat, Diakses 27 Maret 2014.

Mashuri, 2013. Jamban Cemplung (Pit Latrine), Jakarta : Michell

Masriadi, 2014. Epidemiologi Penyakit Menular. Depok : Rajawali Press

Misnadiarly, 2010. Infeksi Saluran Pernapasan Akut.

Miranda, 2016. Memenuhi syarat Rumah. Jakarta : Salemba Medika

Mumpuni, 2016. 45 Penyakit menular. Yogyakarta : Rapha Publishing

Muttaqin, 2008. Infeksi Saluran Pernafasan Akut. Jakarta : Salemba Medika

Notoatmodjo, S., 2010a. IImu Kesehatan Masyarakat. Jakarta: Rineka Cipta

Rahajoe, 2010. Infeksi Saluran Pernafasan Akut. Jakarta : Medika

Sarwono, 2013. Kepadatan dan kesesakan tempat tinggal. Diakses 31Maret 2011

Suryono. 2012. Hubungan kondisi fisik rumah dengan kepadatan hunian.

Diakses 09 April 2014.

Widayono, 2010. Infeksi Saluran Pernafasan. Jakarta : Rineka Cipta

World Health Organization. 2015. Pencegahan dan Pengendalian ISPA difasilitasi pelayanan kesehatan. Dinkes. 10 mei 2017 